\title{
Language Transitivity of Angkola Farmer
}

\author{
Husniah Ramadhani Pulungan \\ Universitas Sebelas Maret \\ Surakarta, Indonesia \\ husniahpulungan@gmail.com
}

\author{
Djatmika \\ Universitas Sebelas Maret \\ Surakarta, Indonesia \\ djatmika26@gmail.com
}

\author{
Riyadi Santosa \\ Universitas Sebelas Maret \\ Surakarta, Indonesia \\ rst@uns.ac.id \\ Tri Wiratno \\ Universitas Sebelas Maret \\ Surakarta, Indonesia \\ wiratno.tri@gmail.com
}

\begin{abstract}
An Angkola farmer is a farmer from Angkola, South Tapanuli, North Sumatra, Indonesia. The Angkola farmer has an interesting transitivity to be examined when viewed from the underlying culture. The farmer studied was 68 year old farmer. The selection of the farmer is done because the more senior means the more life experiences can be conveyed so that the descriptions of the participant constituents, the process constituents, and the circumstantial constituents can be properly established. Through interviews, the data last for about $\mathbf{2 0}$ minutes. The analysis of this study shows that the use of constituent participants: ellipsis by farmer is as much as $\mathbf{5 1 . 5 3 \%}$, the use of process constituents: material; doing is as much as $\mathbf{5 1 , 7 8 \%}$, the use of process: behavioral: mental is $13,69 \%$, process usage: mental: affective is $10,71 \%$, use of constituent circumstance: location: place is $\mathbf{2 6 , 4 1 \%}$, and the use of circumstance: cause: behalf is as much as $25.47 \%$. Based on the exposure, it can be stated that the Angkola farmer is a simple person, that is, sincere, hardworking, loyal, responsible, not easily despaired, and grateful for what God has given to him.
\end{abstract}

Keywords - transitivity; farmer; angkola; language; material

\section{INTRODUCTION}

Angkola is an area in South Tapanuli Regency, North Sumatra Province, Indonesia with an area of 4,367.05 square kilometer. According to SP2010 data and according to Permendagri No.39/2015, the aggregate population is 264,108 (District Goverment of Tapanuli Selatan, 2011). In general, Angkola people are farmers and planters. Coffee, rice, salak, rubber, cocoa, coconut, cinnamon, chilli, onion, leek, and vegetables are the agricultural products in Angkola in general (Hasibuan, 1972). Experience in farming by Angkola farmers allegedly produces a unique transitivity. The uniqueness of transitivity in question will arise when viewed in terms of farmer.

Selection of transitivity as one of the areas which is analyzed this time because transitivity is related to one's experience. This is because transitivity is a grammar that discusses clause structures that represent ideational meanings: experimental. This structure realizes the meaning of an experience whose reality has three constituents, namely: process, participants, and circumcision (Santosa, 2003, p. 78)
The above statement is supported by a theory which states that the transitivity system provides a lexicogrammatical source to construct a quantum change in the incident flow as a figure - as a configuration of the main center of a process. The process can turn into a regular sequence of the kinds of processes (Halliday in Matthiessen, 2014, p. 213). Furthermore, the types of processes contained in transitivity divide work processes in transitivity into three steps, namely: process type, participant, and circumcision (Thompson, 2014, p. 132).

The theoretical basis is the author's guide in researching this transitivity. Based on the three constituents in transitivity, only the constituents of the Angkola farmers are chosen. In order to answer the question of how transitivity is owned by Angkola farmers, three questions are proposed proposed: (1) What is the description of the participants constituents produced by Angkola farmers? (2) What is the description of the process constituents produced by Angkola farmers? What is the description of the circumstantial constituents produced by Angkola farmers?

The purpose of this study is to describe the constituents of participants, the process constituents, and the circumstantial constituents resulting from the transitivity of Angkola farmers. The benefit of this research is to add theoretical building in the study of Angkola language especially in the perspective of Systemic Functional Linguistics related to transitivity in the language of Angkola farmers. In addition, this research is useful as a documentation and inventory of cultural wealth of the archipelago that must be preserved.

\section{LITERATURE REVIEW}

This research was conducted after tracing several studies related to farmers and their languages (Miller, 2001; Diamond \& Belwood, 2003; Haryanti \& Budi, 2007; Fernandez, 2008; Handaka \& Surokim, 2014; Sari, 2015; Jain \& Singla, 2015; Arnawa, 2016; Raungvaka \& Savetvanupong, 2017; Mwaniki, et al., 2017; up to Kapeleka \& Mwaseba, 2017). Previous researches analyzes the language of the peasant which includes his kinship language; its first expansion; ethnic expression; categories and linguistic expressions; communication patterns; empowerment of technology and information; use of cellular technology for knowledge dissemination among 
farmers; shifting vocabulary in agriculture; information orientation; overcoming challenges in communicating adaptation practices through radio intervention; effectiveness of pesticide label as a communication tool for small farmers about pesticide handling.

Based on the theoretical review above it can be explained that research on farmers so far still discusses about the communication and the language expression of farmer. In fact, even farmer communication has been supported by various media. However, research findings related to the transitivity of farmers are still limited.

Thus, this research gap is in the language of farmer from the perspective of Systemic Functional Linguistics, especially in its transitivity. The analyzed is a constituent of participant, process, and circumtance of language transitivity from Angkola farmer. What makes this research interesting is that the informant interviewed was an old farmer who was considered to have had a lot of grief experience in farming.

\section{METHOD}

The research method used is descriptive qualitative. The selected informant was a 68-year-old Angkola farmer. The research location was at Batu Horpak Village, Tano Tombangan Angkola Sub-district, South Tapanuli District, North Sumatera Province, Indonesia. The source of the data is spoken data of Angkola farmers' talks. Then the spoken data is transcribed and analyzed per clause in accordance with the needs of its transitivity analysis. Technique of data collection is interview lasting for 20 minutes. The data were analyzed by using Systemic Functional Linguistic approach.

\section{RESUlT AND DisCUSSION}

\section{A. Description of Participants Constituents of Angkola Farmer}

The types of participant constituents include actors of the process, something that is subjected to a process, a phenomenon, or something being said, and so on depending on the type of process. This participant is represented by the noun group (Santosa, 2003, p. 78). Based on this theory, constituents of participants from Angkola farmer can be seen in Table I. below.

\section{TABLE I. CONSTITUENT OF PARTICIPANT}

\begin{tabular}{|c|c|c|c|}
\hline $\begin{array}{l}\text { Constituent } \\
\text { of Participant }\end{array}$ & Form & Quantity & $\%$ \\
\hline $\begin{array}{l}\text { Tutur 'said } \\
\text { manners' }\end{array}$ & $\begin{array}{l}\text { Ompung } \\
\text { 'Grandmother/Grandfathe } \\
\text { r', Anggi 'little sister/little } \\
\text { brother', amatta 'our } \\
\text { father', kahanggi } \\
\text { 'brother/sister', inang } \\
\text { 'mother', umakku 'my } \\
\text { mother' }\end{array}$ & 6 & $3,68 \%$ \\
\hline Attached & $\begin{array}{l}\text { Hu- 'I' } \\
\text { Hudokkon 'I tell' } \\
\text { Hupaupaon 'I hired' } \\
\text { Hubaen 'I made' } \\
\text { Huida 'I see' } \\
\text { Hupature 'I fix it' } \\
\text { Huingot 'I remember' } \\
\text { Hupadiar 'I let it' }\end{array}$ & 8 & $4,90 \%$ \\
\hline
\end{tabular}

\begin{tabular}{|c|c|c|c|}
\hline & Hurasa 'I feel' & & \\
\hline & $\begin{array}{l}\text {-nami 'our' } \\
\text { Ombarnami 'our } \\
\text { neighbors' }\end{array}$ & 1 & $0,61 \%$ \\
\hline & $\begin{array}{l}\text {-nia 'his/her' } \\
\text { Dosania 'his sin' } \\
\text { Sabania 'his rice fields' } \\
\text { suruhanNia 'his } \\
\text { messenger' } \\
\text { laranganNia 'his } \\
\text { prohibition' }\end{array}$ & 4 & $2,45 \%$ \\
\hline & $\begin{array}{l}\text {-niba 'of us' } \\
\text { Angginiba 'sister of us' } \\
\text { Tesniba 'drink of us' } \\
\text { Indahanniba 'rice of us' } \\
\text { Dosaniba 'sin of us' }\end{array}$ & 4 & $2,45 \%$ \\
\hline & $\begin{array}{l}\text {-ku 'my' } \\
\text { Ombarku 'my neigbor' } \\
\text { Emekku 'my rice' } \\
\text { Sabakku 'my rice fields' } \\
\text { Giotku 'my wish' } \\
\text { Holong ni rohakku 'my } \\
\text { love' } \\
\text { Dosakku 'my sin' }\end{array}$ & 6 & $3,68 \%$ \\
\hline & $\begin{array}{l}\text {-mu 'your' } \\
\text { Kahanggimu 'your } \\
\text { brother' }\end{array}$ & 1 & $0,61 \%$ \\
\hline Ellipsis & $\begin{array}{l}\text { Porsaya (porsaya do au) } \\
\text { 'believe (I believe)' } \\
\text { Markunjung tu son } \\
\text { (markunjung do au tuson) } \\
\text { 'visited here (I visited } \\
\text { here), and so on. }\end{array}$ & 84 & $51,53 \%$ \\
\hline Noun & $\begin{array}{l}\text { Rasoki 'sustenance' } \\
\text { Hama-hama 'pests' } \\
\text { Aek 'water' } \\
\text { Eme 'rice' } \\
\text { Same 'seeds' } \\
\text { Racun 'poison' } \\
\text { Ubat 'drug' } \\
\text { Borkat 'blessings' } \\
\text { and so on. }\end{array}$ & 43 & $26,38 \%$ \\
\hline Pronoun & $\begin{array}{l}\text { Au 'I' } \\
\text { Ia 'He/She' } \\
\text { Halahi 'They' } \\
\text { Ko 'You' } \\
\text { Hamu 'You' } \\
\text { Iba 'myself' }\end{array}$ & 6 & $3,68 \%$ \\
\hline$\sum$ & & 163 & $96,29 \%$ \\
\hline
\end{tabular}

Based on the table I, it can be seen that the tendency of Angkola farmers to use elliptical for constituent of participant is $51.53 \%$. This is because the farmer is a very simple person in conveying his thoughts and feelings to others. One of its forms is as follows.

TABLE II. ELLIPSIS

\begin{tabular}{|l|l|l|}
\hline $\begin{array}{l}\text { Marsimulak do } \\
\text { 'Round-trip' }\end{array}$ & $\begin{array}{l}\text { 'I' } \\
\text { Process: material: }\end{array}$ & $\begin{array}{l}\text { Ampung } \\
\text { 'granchild' }\end{array}$ \\
\hline happening & goal \\
\hline \multicolumn{2}{|l|}{ 'I round trip grandchildren' } \\
\hline
\end{tabular}

The table II shows that in the language of Angkola farmers, ellipsis is found in the actor 'I' which should appear but not included in the farmers' speech. However, the researcher can understand that according to the context of the interview the farmer refers to herself. 
Based on the above description it can be stated that Angkola farmers tend to use participant constituents in ellipsis form. This is because farmers are field practitioners so their way of working reflects how they communicate with others. The selection of minimalist participants shows a very practical and simple figure in everyday life.

\section{B. Description of Process Constituents of Angkola Farmer}

Process in the event is the essence of an experience, be it physical, mental, verbal, behavioral, relational, and existential experience that is represented by a verb group (Santosa, 2003, p. 78). Here is constituent of process from the language of Angkola farmer.

\section{TABLE IV. CONSTITUENT OF PROCESS}

\begin{tabular}{|l|l|l|l|}
\hline $\begin{array}{c}\text { Constituent } \\
\text { of Process }\end{array}$ & Form & Quantity & \multicolumn{1}{|c|}{$\%$} \\
\hline \multirow{2}{*}{ Material } & Happening & 14 & $8,33 \%$ \\
\cline { 2 - 4 } & Doing & 87 & $51,78 \%$ \\
\hline \multirow{3}{*}{ Mental } & Perceptive & 6 & $3,57 \%$ \\
\cline { 2 - 4 } & Affective & 18 & $10,71 \%$ \\
\cline { 2 - 4 } & Cognitive & 4 & $2,38 \%$ \\
\hline Verbal & & 7 & $4,16 \%$ \\
\hline \multirow{3}{*}{ Behavioural } & Verbal & 6 & $3,57 \%$ \\
\cline { 2 - 4 } & Mental & 23 & $13,69 \%$ \\
\hline Relational & & 1 & $0,59 \%$ \\
\hline Existential & & 2 & $1,19 \%$ \\
\hline & $\sum$ & 168 & $99,97 \%$ \\
\hline
\end{tabular}

The table above explains that Angkola farmers tend to use material process constituents as much as $51.78 \%$. This shows that because farmers work more in the field and use physical activity, the process that is often used is doing. The process form can be seen in the following table.

\section{TABLE V. PROCESS: MATERIAL: DOING}

\begin{tabular}{|l|l|l|}
\hline $\begin{array}{l}\text { Adong modalnia non } \\
\text { 'There is capital later' }\end{array}$ & $\begin{array}{l}\text { manabusi } \\
\text { 'buy' }\end{array}$ & $\begin{array}{l}\text { pupuk na deges- } \\
\text { deges akka ubatna } \\
\text { 'good fertilizer as a } \\
\text { medicine' }\end{array}$ \\
\hline actor & $\begin{array}{l}\text { proses: material: } \\
\text { doing }\end{array}$ & goal \\
\hline \multicolumn{2}{|l|}{ 'There is the capital will buy a good fertilizer as a medicine' } \\
\hline
\end{tabular}

Manabusi 'buy' is a material process: doing because manabusi is a transitive verb which is done by using the physical hand to make a purchase. This process requires a goal that is fertilizer na deges-deges akka ubatna 'good fertilizer as a medicine'. This cannot be separated from adong modal nia non 'there is capital later' as actor. So, the pattern is actor + process + goal.

Next, the second process constituent tendency is process: behavioral: mental as much as $13.69 \%$. One of the forms can be seen in the following table.

TABLE VI. PROCESS: BEHAVIOURAL: MENTAL

\begin{tabular}{|l|l|}
\hline $\begin{array}{l}\text { Manjalaki } \\
\text { 'Looking for' }\end{array}$ & $\begin{array}{l}\text { ngolu-ngolu } \\
\text { 'life' }\end{array}$ \\
\hline Process: mental behavioural & Phenomenon \\
\hline 'Looking for life' \\
\hline
\end{tabular}

Manjalaki 'looking for'is mental behavioural because this process is a combination of mental process and material process. The constituent of participant have already joined in the constituent of process. The phenomenon is ngolungolu 'life'. The next pattern is process + phenomenon.

The use of process: behavior: This mentality occurs because the farmer has a mental element behind the physical body. In other words, farmers have a high mental attitude because that behavioural is always dealing with the process of growing rice from seeds to rice. This mental attitude that fosters the soul is responsible of the farmer's dedication to his work.

Next, the constituent often used by farmers is process: mental: affective as much as $10.71 \%$.

TABLE VII. PROCESS: MENTAL: AFFECTIVE

\begin{tabular}{|l|l|}
\hline $\begin{array}{l}\text { Cocok hurasa } \\
\text { 'fit I feel' }\end{array}$ & $\begin{array}{l}\text { tu au } \\
\text { 'to me' }\end{array}$ \\
\hline $\begin{array}{l}\text { Pro- senser- ses: mental: } \\
\text { affective }\end{array}$ & 'sirumstance: cause: purpose \\
\hline 'I feel fit to me' & \\
\hline
\end{tabular}

Cocok hurasa 'fit I feel' is a combination of process and senser. The senser attaches between the processes of $h u$ 'I' and rasa 'feel '. Rasa is an affective process because it uses the heart. In addition this clause ends with $t u a u$ 'to me' as circumstance of cause purpose. So the pattern is pro- + senser +-cess + circumsntance.

The mental: affective used because more farmers use their feelings and heart in work. This shows the sincerity of the trained farmer at the time of taking care of the rice field with all its problems. Although the pests or sometimes the season is less supportive, farmers stay sincere is taking care of the fields until the harvest time comes.

\section{Description of Circumstance Constituents of Angkola Farmer}

Circumstance is the environment both physical and non physical in the event that is represented by adverb group (Santosa, 2003, p. 78). The description of the circular constituents of farmers can be seen in the following table.

TABLE VIII. CONSTITUENT OF CIRCUMSTANCE

\begin{tabular}{|c|c|c|c|}
\hline $\begin{array}{l}\text { Circumstance } \\
\text { Constituent }\end{array}$ & Form & Quantity & $\%$ \\
\hline Angle & & 5 & $4,71 \%$ \\
\hline \multirow[t]{2}{*}{ Location } & Time & 11 & $10,37 \%$ \\
\hline & Place & 28 & $26,41 \%$ \\
\hline Eksten & & 4 & $3,77 \%$ \\
\hline \multirow[t]{3}{*}{ Manner } & Kualitas & 13 & $12,26 \%$ \\
\hline & Means & 1 & $0,94 \%$ \\
\hline & Comparison & 2 & $1,88 \%$ \\
\hline \multirow[t]{5}{*}{ Cause } & Condition & 3 & $2,83 \%$ \\
\hline & Alasan & 3 & $2,83 \%$ \\
\hline & Tujuan & 2 & $1,88 \%$ \\
\hline & Konsesi & 3 & $2,83 \%$ \\
\hline & Behalf & 27 & $25,47 \%$ \\
\hline Accompaniment & & 3 & $2,83 \%$ \\
\hline Role & & 1 & $0,94 \%$ \\
\hline \multicolumn{2}{|c|}{$\sum$} & 106 & $99,95 \%$ \\
\hline
\end{tabular}


Based on the table VIII, it can be explained that Angkola farmers tend to use circumstance: location: place as much as $26.41 \%$ in their daily life. This data show that it is true that farmers spend most of their lives in the fields. One form of circumstance: this place can be seen in the following table.

TABLE IX. CIRCUMSTANCE: LOCATION: PLACE

\begin{tabular}{|l|l|l|}
\hline $\begin{array}{l}\text { Motci } \\
\text { 'Rats' }\end{array}$ & $\begin{array}{l}\text { mate } \\
\text { 'die' }\end{array}$ & $\begin{array}{l}\text { di sabakki } \\
\text { 'in my rice fields' }\end{array}$ \\
\hline & & $\begin{array}{l}\text { Circumstance: } \\
\text { location: place }\end{array}$ \\
\hline \multicolumn{2}{|l|}{ 'Rats have died in my rice fields' } \\
\hline
\end{tabular}

The table IX explains that in sabakki 'in my rice fields' is a circumstance: location: place. This is because most of the activities of farmers from morning to evening are in the fields. Thus, it cannot be denied that farmers will tend to use this circumstance in conveying their thoughts to others.

Next, the tendency of the second use of circumstance by the farmer is circumstance: cause: behalf as much as $25.47 \%$, such as the table $\mathrm{X}$ below.

TABLE X. CIRCUMSTANCE: CAUSE: BEHALF

\begin{tabular}{|l|l|}
\hline $\begin{array}{l}\text { Anggo au } \\
\text { 'according to me' }\end{array}$ & $\begin{array}{l}\text { Inda pala hubaen } \\
\text { 'I don't really make it' }\end{array}$ \\
\hline Circumstance: cause: behalf & \\
\hline 'According to me, I don't really make it' \\
\hline
\end{tabular}

In accordance with the table $\mathrm{X}$, it can be explained that anggo au 'according to $\mathrm{me}^{\prime}$ is the circumstance: cause: behalf because the farmer conveyed something based on the experience that has passed. Thus, the peasants convey their thoughts and feelings to others based on life experiences that have been gone through so that farmers can convey the joys of life as a valuable lesson for others who need it.

The research analysis, the participant constituents, process constituents, and circumstance constituents of Angkola farmers have represented the original life of the farmer. Physical activity that is mostly done in the field fosters the experience and the way the farmers look at things is practical and simple. In addition soft skill that is embedded in farmers is ranging from sincere, hardworking, loyal, to responsible. Because whatever happens to his rice field he will keep and protect the paddy wholeheartedly as her own child. Farmer survive on crops so that they always mean every day in the care of their fields. Although sometimes experiencing crop failure farmer remain grateful to God for realizing that the sustenance of each person has been determined. It's just that the peasants strongly believe that by working hard will give the best results according to God's provisions. The positive thing shown by the farmer is toughness, hard work, and desperate attitude in the face of life's grief.

\section{V.CONCLUSION}

Based on data analysis, the use of constituent participants: ellipsis by farmers which is as much as $51.53 \%$ as a proof that the farmer is a simple and practical person. The use of process constituents: material; doing $51.78 \%$ indicates that farmers are identical with physical activity and hard workers. In addition process: behavior process: mental is as much as $13.69 \%$ indicating that farmer also uses mental attitude in taking decision when doing his work in the fields. It is also identified that the use of the process: mental: affective is as much as $10.71 \%$ indicating that farmers work sincerely.

Furthermore, the tendency of the use of constituent circumstance: location: place is as much as $26.41 \%$ which indicates that farmer do work in the field in this case rice field, so this circumstance cannot be separated from the life of the farmer. Next, circumstance which is also often used by farmers is the circumstance: cause: behalf as much as $25.47 \%$ which shows the peasant's way of perceiving something. Thus, according to the exposition, it can be stated that the Angkola peasant is a simple person, who is, sincere, hardworking, loyal, responsible, not easily discouraged, and grateful for what God has given him.

\section{Acknowledgment}

I thank to PRASASTI 2018 for accepting me to attend this occasion. I thank to BUDI DN-LPDP RI scholarship for sponsoring me. I really appreciate it. I am very grateful to the advisor and the co advisors from Universitas Sebelas Maret Surakarta who has supported me to participate in this event.

\section{References}

Anna Carew-Miller. (1993). The language of domesticity in creve coeur's letters from an american farmer. Early American Literature, 13(28), 242-254. Retrieved from https://doi.org/10.1257/0002828041464551

Arnawa, N. (2016). Pergeseran kosakata bahasa Bali ranah pertanian: studi linguistik kebudayaan. Aksara, 28(1), 103-110. Retrieved from http://dx.doi.org/10.29255/aksara.v28i1.21.103-110

Diamond, J., \& Bellwood, P. (2008). Farmers and their languages: the first expansions. Nature (London), 300(5619), 597-603. Retrieved from www.scincemag.org

District Goverment of Tapanuli Selatan. (2011). Sejarah Tapanuli Selatan. Retrieved from http://www.tapanuliselatankab.go.id/2011/07/geografi.h $\underline{\mathrm{tml}}$

Fernandez, I. Y. (2008). Kategori dan ekspresi linguistik dalam bahasa Jawa sebagai cermin kearifan lokal penuturnya: kajian etnolinguistik pada masyarakat petani dan nelayan. Kajian Linguistik dan Sastra, 20(2), 166-177. Retrieved from http://journals.ums.ac.id/index.php/KLS/article/view/49 66/3289 
Handaka, T. dan S. (2014). Pola komunikasi kelompok petani tembakau Madura sebagai basis penyusunan kebijakan pemberdayaan. KARSA, 23(2), 223-239. Retrieved from http://dx.doi.org/10.19105/karsa.v22i2.527

Haryanti, D., \& Budi, A. (2007). Ungkapan etnis petani Jawa di Desa Japanan, Kecamatan Cawas, Kabupaten Klaten: kajian etnolinguistik. Kajian Linguistik Dan Sastra, 19(1), 35-50. https://doi.org/10.23917/kls.v19i1.4408

Hasibuan, Mahmud Fauzi. (1972). Perbandingan pantun Indonesia dan pantun Angkola. Padangsidimpuan: Fakultas Keguruan Sastera dan Seni Institut Keguruan dan Ilmu Pendidikan Negeri Medan.

Jain, L., Kumar, H., \& Singla, R. K. (2015). Assessing mobile technology usage for knowledge dissemination among farmers in Punjab. Information Technology for Development, 21(4), 668-676. Retrieved from https://doi.org/10.1080/02681102.2013.874325

Kapeleka, J., \& Mwaseba, D. L. (2017). Effectiveness of pesticide labels as a communication tool for smallholder farmers on pesticides handling, 6(02), 50-60. Retrieved from http://www.ijstr.org/finalprint/feb2017/Effectiveness-Of-Pesticide-Labels-As-ACommunication-Tool-For-Smallholder-Farmers-OnPesticides-Handling.pdf

Matthiessen, Christian M.I.M. (2014). Halliday's introduction to functional grammar. New York: Routledge.

Mwaniki, F., Gichuki, C., Mwangi, M., Mburia, P., \& Wandago, B. O. (2017). Addressing challenges in communicating adaptation practices to smallholder farmers in Kenya through a radio intervention. Journal of Agricultural and Environment for International Development, 111(2), 279-322. Retrieved from http://dx.doi.org/10.12895/jaeid.20172.589

Raungpaka, V., \& Savetpanuvong, P. (2017). Information orientation of small-scale farmers' community enterprises in Northern Thailand. Kasetsart Journal of Social Sciences, 38(3), 196-203. Retrieved from https://doi.org/10.1016/j.kjss.2016.08.018

Santosa, Riyadi. (2003). Semiotika sosial, pandangan terhadap bahasa. Surabaya: Pustaka Eureka.

Sari, D. A. (2015). Evaluasi program pemberdayaan petani melalui teknologi dan informasi pertanian usaha ternak domba. EconomicMs Development Analysis Journal, 4(1), 16-24. Retrieved from http://journal.unnes.ac.id/sju.index.php/edaj

Thompson, Geoff. (2014). Introducing functional grammar. New York: Routledge. 